\title{
Investigation of the Readiness of Ground Soils for the Installation of Ground Heat Exchange Systems in Baghdad City
}

\author{
Salam J. Bash Al-Maliky \\ Environmental Engineering, AlMustansiriya University-Iraq \\ Faculty and Leader in Residence, Ohio University, USA \\ E-mail: salambash2000@yahoo.com
}

Received: June 15, 2011 Accepted: July7, 2011 doi:10.5539/jgg.v3n1p200

\begin{abstract}
This paper was meant to bench mark the possibility of the use of underground soils of Baghdad, Iraq for the installation of Ground Heat Exchange (GHE) systems for heating and cooling purposes in order to reduce the consumption of fossil fuels that were used in conventional plants and the related economic and environmental pollution aspects. Ten thermocouples were installed in each location, at different depths down to 4.5m at AlSadr and AlKry`at cities, north eastern side of Baghdad, in order to record their daily temperature trends at different times for four months; namely January, April, July and October of 2010. The relevant soil thermal properties were tested at different depths to incorporate their possible variations. Both locations had proved high chances to host summer horizontal cooling systems at $3 \mathrm{~m}$ depths or more, where higher than 20C negative temperature differences were recorded as compared with ground surface temperatures, while positive differences were determined to be around 7C and 10C at 4m depth for AlKry at and AlSadr cities respectively during winter times, which suggest that they may serve for preheating systems during these times.
\end{abstract}

Keywords: Baghdad, GHE,Heat transfer, Renewable energy, Soil properties,Underground temperature

\section{Introduction}

Heating and cooling systems were considered for long times as of the most important requirements for numerous industrial, commercial and municipal uses for which huge budgets were allocated for their installation, operation and maintenance, and according to the Economist (Nov 25th 2010) the worldwide spending on these systems were estimated to exceed $\$ 145$ billion a year, nevertheless this tends to increase with the increase of fuel prices. That and the environmental pollution problems related to the conventional systems; such as the emission of greenhouse gases (Energy Information Administration, US Department of Energy,2007), had led to the worldwide propensity to explore other non-conventional forms of such systems that adopt renewable energy sources. Heating/cooling systems that were based on the Ground Heat Exchange (GHE) were of these options that found various applications in USA, Canada and many European countries since it was first described by Lord Kelvin in 1853 and developed by Peter Ritter von Rittinger in 1855 (International Ground Source Heat Pump Association, 2009). The U.S. Environmental Protection Agency (EPA) has called GHE the most available environmentally clean, energy-efficient, and cost-effective space conditioning systems. Heat pumps had offered significant emission reductions potential, particularly where they were used for both heating and cooling and where the electricity was produced from renewable resources (Greenhouse Gas Technology Center, 2005).

In theory, heat can be exchanged between any mediums that have temperature differences no matter how big these differences were, but bigger ones allow higher performance of such process. The GHE may use shallow ground as a source of heat for the cooling fluid that flows in underground horizontally buried loopsif land spacepermits, or otherwise vertically by means of boreholes, thus taking advantage of its seasonally moderate temperatures. In the summer, the process can be reversed to extract heat from buildings and transfer it to the ground. Transferring heat to a cooler medium takes less energy, so the bigger the temperature differences between the two involved mediums, the higher the cooling efficiency of the GHE. Geothermal energy was one form of renewable energy, to heat and air-condition buildings that have become increasingly attractive following the many significant developments in GHE systems. Groundwater flow in the relevant areawould enhance heat exchange that occurs through the dual mechanism of conduction in the aquifer material and convection in the groundwater itself(Hwang, Ooka and Namb, 2010). 
The rate at which heat is conducted through a material is proportional to the area normal to the heat flow and to the temperature gradient along the heat flow path. For a one dimensional, steady state heat flow the rate is expressed by Fourier's equation:

$$
Q=k A \frac{\Delta T}{d}
$$

Where:

$\mathrm{Q}=$ rate of heat flow, $\mathrm{W}$

$\mathrm{k}=$ thermal conductivity, $\mathrm{W} / \mathrm{m}-\mathrm{K}$

$\mathrm{A}=$ contact area, $\mathrm{m}^{2}$

$\mathrm{d}=$ distance of heat flow, $\mathrm{m}$

$\Delta \mathrm{T}=$ temperature difference, $\mathrm{K}$

Hence, the design objective for any GHE configuration is to determine theproper combination of involved materials (heat exchange mediums)for their thermal properties, and pipingdimensions; lengthanddiameter, whichwouldresult absorbing or rejecting the required amount of thermal energy.In addition to that, it is essential to assess the existence of sufficient and steady soil/fluid temperature difference at certain ground depth(s) where GHE system is to be installed in order to guarantee efficient and continuous performance.

The difficult part in the process is to predict the thermal response of the soil surrounding thepipe through which either hot or cold water is circulated. Although Kasuda and Archenbach had presented, since 1965, a model describing the temperature distribution in the ground that linked the temperature of the ground to the time of the year, the depth and thermal diffusivity of the ground (Florides and Kalogirou, 2005), that was used in various formsby many researchers such asWilliams and Gold (1976) to estimate the range of the ground temperature in Canada,itwas not applicable to have certain model for such predictions that may workwith high degree of precision anywhere,because it depends on many factors such as the operatingstrategy of the system, the GHE geometry, and local soil and climatic conditions, which may change accordinglybychangingthe sites.

The thermal properties such as thermal conductivity and specific heat and hydraulic properties of the ground are very important to accuratelypredict heat transfer between the ground heat exchanger and the ground. A geotechnicalsurvey reduces the uncertainty in the determination of the groundthermal properties. More accurate information on the groundproperties can save costs by allowing the heat exchange loop length to bereduced. Also, factors like slope orientation, terrain, solar radiation, wind, rain, etc., can have influence on the thermal behavior of the ground, so it is very important to be aware of the extent of the influence and how they affect it (Charoenvisal, 2008).

The goal of this study was to investigate the readiness of underground soils of Baghdad, Iraq for the installation of steady long term and efficient GHE systems. This includes the test of temperature differences and trends, at different depths as compared with the prevailing atmospheric temperatures during summer and winter times, in addition to the test of soil properties and their possible variation with depth.

\section{Experimental settings}

The temperature trend of different ground soils in Baghdad, the ancient capital of Iraq, at different depths was tested to assess the possibility of the adoption of ground heat exchange cooling/heating systems in order to reduce the cost of power and overcome the need to complex techniques for such purposes. Two locations at AlSadr city and Alkry at city were selected for these testes. Both of these locations were located north of Baghdad at the eastern side of the famous river, Dijla that was also known as Tigress(Fig.1).In each location, $4.5 \mathrm{~m}$ deep boreholes were made to incorporate Omega thermocouples (K-type) at various depths in order to measure theground temperature.Data were collected via AEMC Thermocouple Simple Logger II, on daily basis, four times a day; 6 AM, 1:00 PM, 6:00 PM and midnight, for each of the 10 thermocouples installed at depths zero to $4.5 \mathrm{~m}$ from ground level with $50 \mathrm{~cm}$ depth intervals.Also, ground soils of study areas were tested for their main heat exchange related propertiescomposition, density (compaction test) and thermal heat conductivity (ASTM D 5334-08 Standard Test). Samples for these tests were taken from different depths in order to investigate any possible variances of properties with depth. Temperatures of different depths were recorded for the months January, April, July and October of 2010 to include all seasonal changes, which are of crucial significance for steady continuous operation of the tentative heat exchange systems. 


\section{Results and discussion}

Three samples were taken from the soils of each study location at depths $1 \mathrm{~m}, 3 \mathrm{~m}$ and $4.5 \mathrm{~m}$ in order to determine the soil properties related to heat transfer process and investigate any possible variances of them versus depth. Average soil properties of tested locations were listed in Table 1, which demonstrates the higher water content of Alkry'at city`s soil (56\%) that was mainly formed of clay and silt, due tothe agricultural nature of it and its closeness to the river Dijla, ascompared to AlSadr city`s soil that contains sandstones in addition to clay. No significant variances were detected for the tested properties, which reflected a promising factor for stable heat exchange environment within the tested depths that may allow for the adoption of horizontal piping.

The daily temperature records of thermocouples installed on ground level in addition to nine points of $0.5 \mathrm{~m}$ steps down to $4.5 \mathrm{~m}$ underground were collected four times per day; 6:00 AM, 1:00PM, 6:00PM, and midnight, for the months January, April, July, and October, 2010. As it was the temperature difference that plays a crucial role in heat transfer process, the ground level records were subtracted from each temperature record of underground thermocouple to determine these differences that were adopted during any following analysis. These records were averaged for each daily time reading at each certain depth and the statistical analysis of everymonth's records were listed in Table 2 for AlSadr city and Table 3 for Alkry'at city.Temperature differences at different depths as compared to the prevailed temperature at ground levels were demonstrated in Figures 2 to 5 for AlSadr city location at months January, April, July and October respectively, while comparable records were demonstrated in Figures 6 to 9 respectively.

The majority of recorded underground temperature differences had demonstrated almost constant values around the day for each layer, especially below 1.0m depth for both locations as shown in Tables 2 and 3 . In general, it was clear that underground layers were warmer than the ground level during winter time period; January and April, for both tested locations and the positive temperature differences tended to increase with the depth. In contrast, during the summer times, the underground layers were much colder when compared to the ground level temperatures for both locations, and these negative differences were higher as depths increased.Although the temperature change trends with depth seemed similar for both locations during winter and summer times respectively, it was remarked that temperature positive differences of different underground layers during winter times were significantly less than the negatives ones of the same layers during summer times; the maximum positive temperature differences during January and April at $4.5 \mathrm{~m}$ depth for AlSadr city were $11.775 \mathrm{C}$ and $10.575 \mathrm{C}$ respectively, while the same depth had negative temperature differences of $26.55 \mathrm{C}$ and $24.35 \mathrm{Cduring}$ July and October respectively, and similar comparison for AlKry'at city showed results of 7.225C, 7.15C and $28.641 \mathrm{C}, 24.371 \mathrm{C}$ respectively.These comparisons have made it a good referral for the preference of the use these location for cooling during summer times rather than heating during winter.

From another side, it was noticed that during winter times, no significant temperature changes (around 10C) had been recorded for depths less than $3.5 \mathrm{~m}$ for AlSadr location while even deeper thermocouples for AlKry'at location had not recorded such differences. This might be incorporated with the high underground water contents of both locations and the significant underground water flow of Alkry`at land.

The most important results were the significant negative temperature differences of underground layers for both tested locations that may become an encouraging factor to pursue researching other factors for the build of efficient, clean and cheap ground heat exchange systems. Alkry'at location has shown around 20C negative temperature change for depths just below $1.5 \mathrm{~m}$ during July and $2.5 \mathrm{~m}$ during October, while during these two months, comparable negative temperature changes were recorded at depths of $3 \mathrm{~m}$ and $3.5 \mathrm{~m}$ respectively for AlSadr city.

\section{References}

Charoenvisal, K. (2008). Energy performance and economic evaluations of the geothermalheat pump system used in the knowledge works I and II buildings. Blacksburg,Virginia: Virginia Polytechnic Institute and State University; MS thesis.

Economist. (2010). [Online] Available at: www.economist.com (September, 2010).

Energy Information Administration, US Department of Energy (2007). "Voluntary Reporting of Greenhouse Gases, Electricity Emission Factors". [Online] Available at: www.eia.doe.gov.

Florides, G., Kalogirou, S. (2005). Annual ground temperature measurements at variousdepths. In: 8th REHVA World Congress, Clima, Lausanne, Switzerland.

Greenhouse Gas Technology Center. (2005). Test and Quality Assurance Plan. Southern Research Institute, NC, USA. 
Hwang, S., Ooka \& Namb, Y. (2010). Evaluation of estimation method of ground properties for the ground source heat pump system. Renewable Energy, 35, 2123-2130. doi:10.1016/j.renene.2010.01.028, http://dx.doi.org/10.1016/j.renene.2010.01.028

International Ground Source Heat Pump Association. (2009). [Online] Available at: www.igshpa.okstate. edu(March, 2009).

Williams, G. P. \& Gold, L. W. (1976). CBD-180 ground temperatures, National Research Council Canada., Institute for Research in Construction. [Online] Available at: www.irc.nrc-cnrc.gc.ca.

Table 1. Soil properties of tested locations at AlSadr and AlKry`at cities, Baghdad, Iraq.

\begin{tabular}{|l|l|l|l|l|}
\hline \multirow{2}{*}{ composition } & \multicolumn{3}{|l|}{ AlSadr city } & \multicolumn{2}{l|}{ Alkry`at city } \\
\cline { 2 - 5 } & Average & Standard deviation & Average & Standard deviation \\
\hline Major composition & \multicolumn{2}{|l|}{ Clay and sandstones } & \multicolumn{2}{l|}{ Clay and silt } \\
\hline Density $\left(\mathrm{kg} / \mathrm{m}^{3}\right)$ & 1470 & 9.2 & 1350 & 7.8 \\
\hline Water content \% & 44 & 3.232 & 56 & 4.863 \\
\hline Heat conductivity $(\mathrm{W} / \mathrm{m} \mathrm{K})$ & 1.7 & 0.238 & 2.15 & 0.225 \\
\hline
\end{tabular}

Table 2. Statistical analysis for underground temperature differences data at AlSadr City

\begin{tabular}{|c|c|l|l|l|l|l|l|l|}
\hline \multirow{2}{*}{$\begin{array}{c}\text { Depth } \\
\mathrm{m}\end{array}$} & \multicolumn{2}{|c|}{ January } & \multicolumn{2}{c|}{ April } & \multicolumn{2}{c|}{ July } & \multicolumn{2}{c|}{ October } \\
\cline { 2 - 9 } & $\begin{array}{c}\text { Average } \\
\mathrm{C}\end{array}$ & $\begin{array}{c}\text { Standard } \\
\text { deviation }\end{array}$ & $\begin{array}{c}\text { Average } \\
\mathrm{C}\end{array}$ & $\begin{array}{c}\text { Standard } \\
\text { deviation }\end{array}$ & $\begin{array}{c}\text { Average } \\
\mathrm{C}\end{array}$ & $\begin{array}{c}\text { Standard } \\
\text { deviation }\end{array}$ & $\begin{array}{c}\text { Average } \\
\mathrm{C}\end{array}$ & $\begin{array}{l}\text { Standard } \\
\text { deviation }\end{array}$ \\
\hline 0.5 & 1.400 & 0.432 & 1.075 & 0.531 & -3.125 & 0.853 & -3.127 & 2.004 \\
\hline 1.0 & 2.800 & 0.572 & 1.9 & 0.678 & -4.275 & 1.05 & -6.955 & 0.966 \\
\hline 1.5 & 4.125 & 0.736 & 2.95 & 0.772 & -6.625 & 1.15 & -8.475 & 1.374 \\
\hline 2.0 & 4.900 & 0.905 & 3.925 & 1.050 & -12.65 & 2.101 & -13.000 & 2.582 \\
\hline 2.5 & 6.275 & 1.050 & 5.350 & 0.850 & -16.325 & 4.077 & -16.125 & 3.119 \\
\hline 3.0 & 7.300 & 1.169 & 6.475 & 0.928 & -20.975 & 2.957 & -19.750 & 3.304 \\
\hline 3.5 & 9.350 & 1.034 & 7.747 & 1.061 & -22.855 & 2.605 & -21.500 & 3.696 \\
\hline 4.0 & 10.600 & 1.254 & 9.375 & 1.335 & -25.325 & 2.637 & -22.675 & 3.299 \\
\hline 4.5 & 11.775 & 1.297 & 10.575 & 1.286 & -26.55 & 2.162 & -24.350 & 3.396 \\
\hline
\end{tabular}

Table 3. Statistical analysis for underground temperature differences data atAlKry'at City

\begin{tabular}{|l|l|l|l|l|l|l|l|l|}
\hline \multirow{2}{*}{$\begin{array}{c}\text { Depth } \\
\mathrm{m}\end{array}$} & \multicolumn{2}{|c|}{ January } & \multicolumn{2}{c|}{ April } & \multicolumn{2}{c|}{ July } & \multicolumn{2}{c|}{ October } \\
\cline { 2 - 9 } & $\begin{array}{c}\text { Average } \\
\mathrm{C}\end{array}$ & $\begin{array}{c}\text { Standard } \\
\text { deviation }\end{array}$ & $\begin{array}{c}\text { Average } \\
\mathrm{C}\end{array}$ & $\begin{array}{c}\text { Standard } \\
\text { deviation }\end{array}$ & $\begin{array}{c}\text { Average } \\
\mathrm{C}\end{array}$ & $\begin{array}{c}\text { Standard } \\
\text { deviation }\end{array}$ & $\begin{array}{c}\text { Average } \\
\mathrm{C}\end{array}$ & $\begin{array}{c}\text { Standard } \\
\text { deviation }\end{array}$ \\
\hline 0.5 & 1.225 & 0.607 & 2.112 & 1.953 & -5.272 & 3.062 & -4.102 & 1.210 \\
\hline 1.0 & 1.725 & 0.685 & 1.438 & 0.588 & -12.869 & 1.529 & -8.508 & 1.328 \\
\hline 1.5 & 2.675 & 1.192 & 2.065 & 1.117 & -20.100 & 1.773 & -15.291 & 1.187 \\
\hline 2.0 & 3.575 & 1.360 & 3.225 & 0.846 & -22.510 & 2.072 & -17.300 & 1.140 \\
\hline 2.5 & 3.575 & 1.150 & 3.775 & 0.718 & -26.007 & 1.594 & -20.925 & 0.830 \\
\hline 3.0 & 5.125 & 1.068 & 5.100 & 0.761 & -26.827 & 1.516 & -22.620 & 0.947 \\
\hline 3.5 & 6.15 & 1.162 & 5.700 & 0.678 & -27.743 & 0.911 & -23.696 & 0.290 \\
\hline 4.0 & 6.65 & 1.182 & 6.600 & 0.663 & -28.482 & 1.013 & -23.196 & 1.500 \\
\hline 4.5 & 7.225 & 0.953 & 7.150 & 0.544 & -28.641 & 1.384 & -24.371 & 0.477 \\
\hline
\end{tabular}




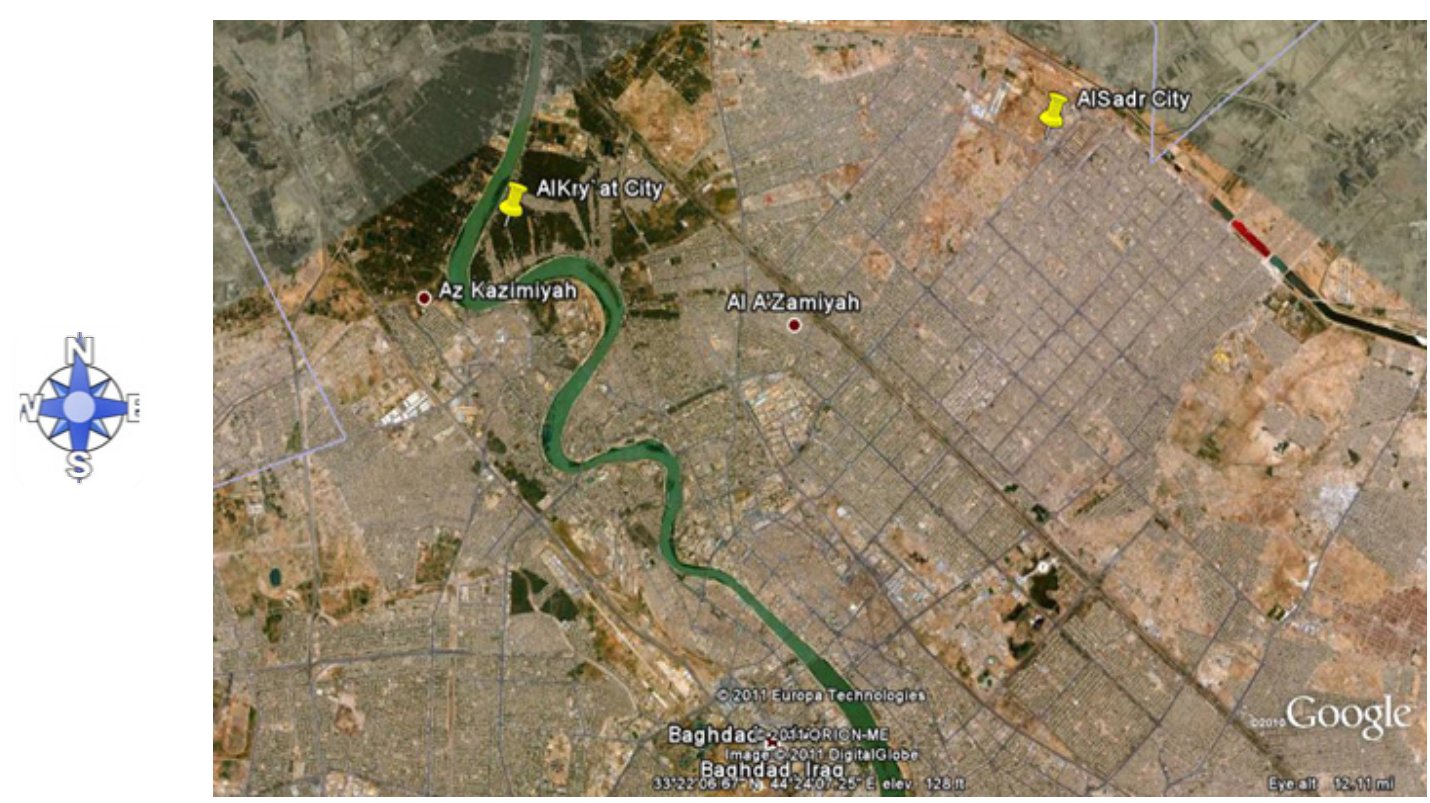

Figure 1. Map of Baghdad city shoring the two locations of study areas. [www.google.com/earth]

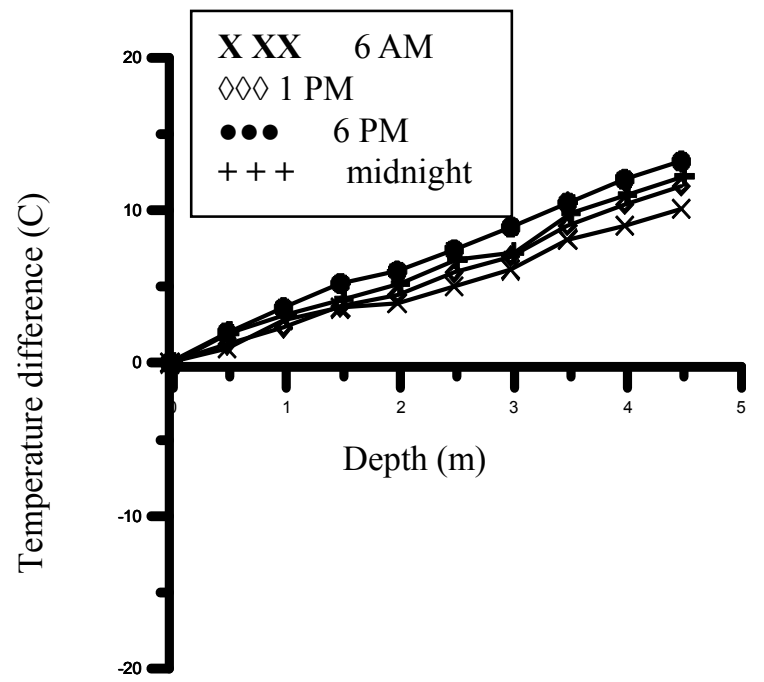

Figure 2. Temperature differences vs. depth at AlSadr city during Jan., 2010

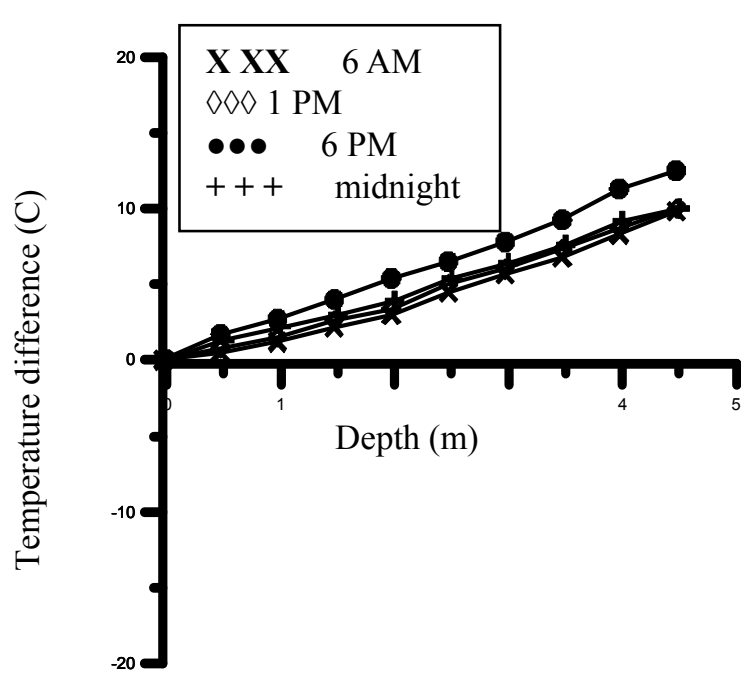

Figure 3. Temperature differences vs. depth at AlSadr city during April, 2010 


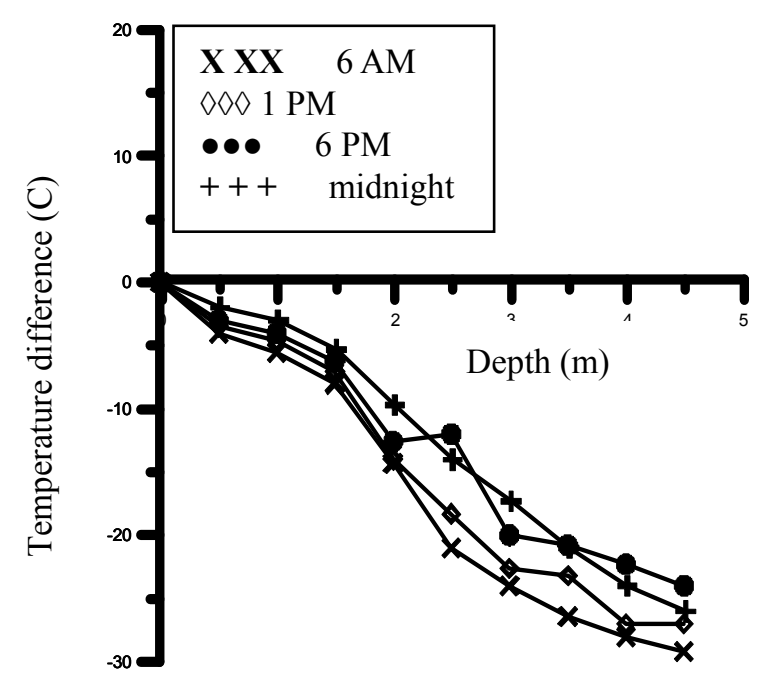

Figure 4. Temperature differences vs. depth at AlSadr city during July, 2010

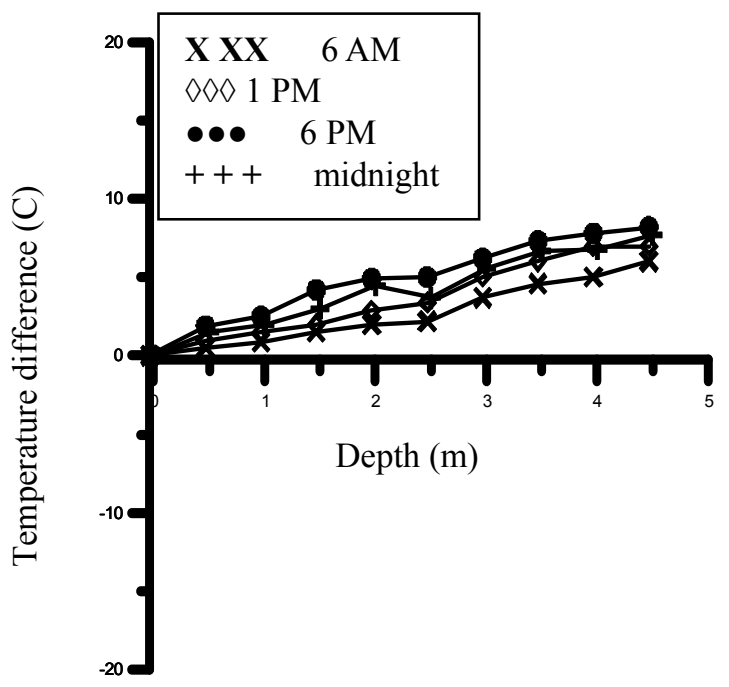

Figure 6. Temperature differences vs. depth at AKry`at city during Jan., 2010

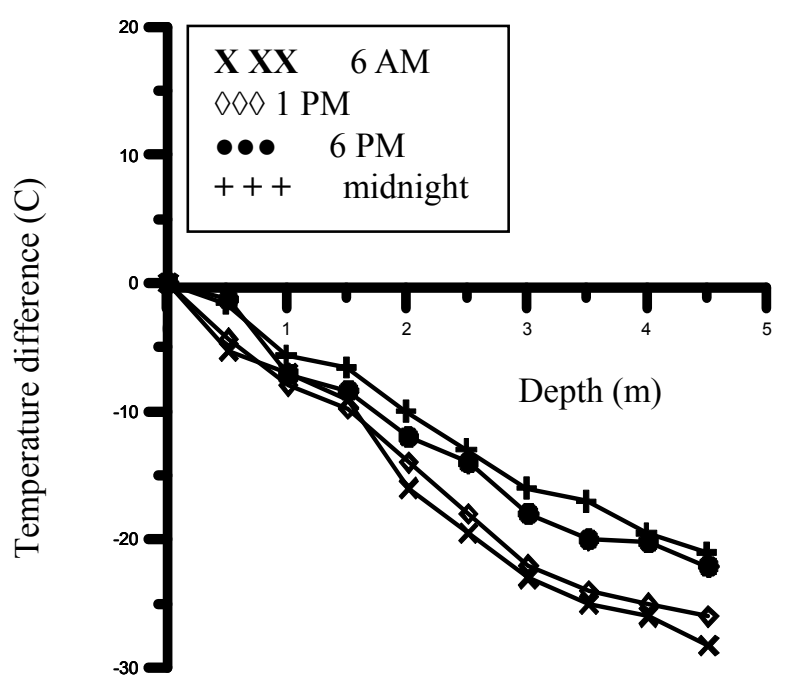

Figure 5. Temperature differences vs. depth at AlSadr city during Oct., 2010

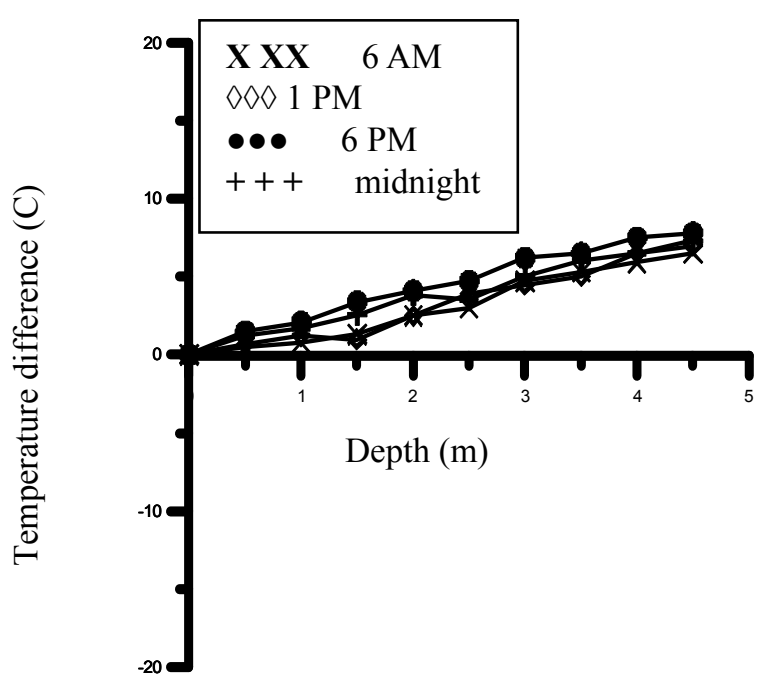

Figure 7. Temperature differences vs. depth at AlKry`atcity during April, 2010 


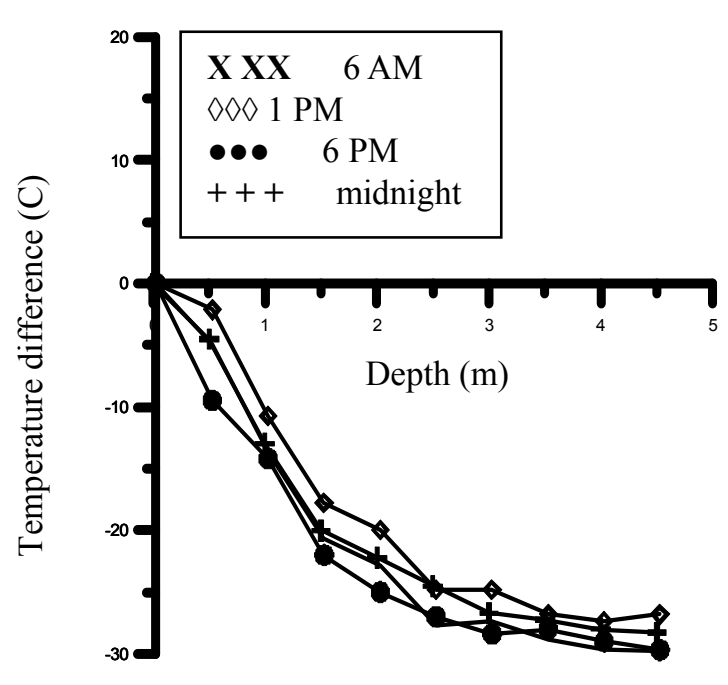

Figure 8. Temperature differences vs. depth at AlKry`at city during July, 2010

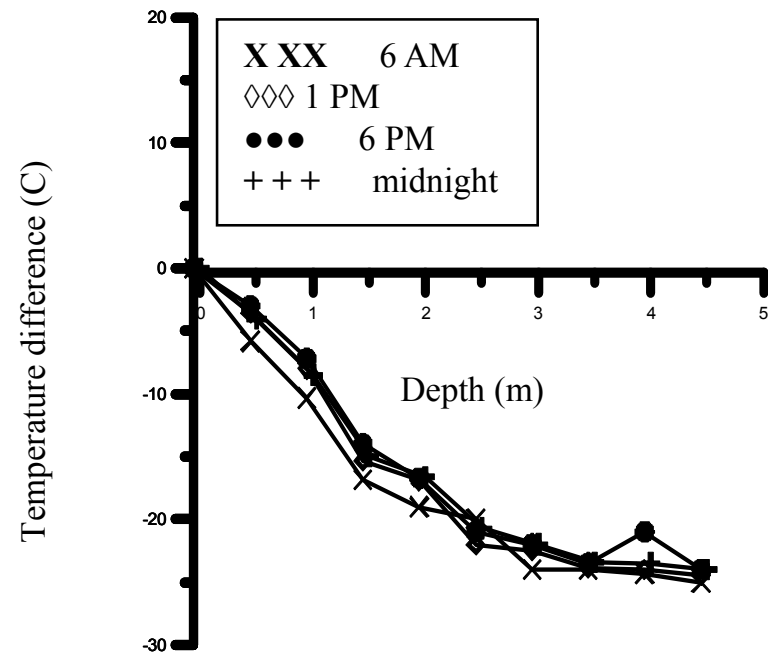

Figure 9. Temperature differences vs. depth at AlKry`at city during Oct., 2010 